$$
\text { 1(1)(2021) 9-16 }
$$

Journal homepage: https://ojs.unikom.ac.id/index.php/injuratech

\title{
Financial Technology as Payment Methods in the Digital Era
}

\author{
I Budiarti1 ${ }^{*}$, F Hibatulloh², M Salman ${ }^{3}$ \\ ${ }^{1}$ Departemen Manajemen, Universitas Komputer Indonesia, Indonesia \\ 2Departemen Teknik Elektro, Universitas Komputer Indonesia, Indonesia \\ ${ }^{3}$ Departemen Ilmu Komunikasi, Universitas Komputer Indonesia, Indonesia \\ Email: *Isniar.budiarti@email.unikom.ac.id
}

\begin{abstract}
FinTech is defined as technological innovation in financial services that can produce business models, applications, processes, or products with material effects related to financial services provision. This study aims to analyze the impact of developing a digital payment system and prevent inflation due to a large amount of cash in circulation. The method used in this study is qualitative. Fintech technology is very beneficial for the community, especially in industrial revolution 4.0, where this digital payment system has advantages and disadvantages. The advantages are efficiency and safety, while the disadvantages are higher interest costs. This digital payment system can minimize inflation due to the large amount of money circulating in society.
\end{abstract}

\section{Introduction}

The evolution of FinTech began with the credit card innovation in the 1960s. Debit cards and terminals that provide cash, such as Automatic Teller Machines (ATMs), were invented in the 1970s [1]. The emergence of telephone banking followed in the 1980s, and then a variety of financial products came to be after capital market deregulation in the 1990s. Furthermore, internet banking encouraged the existence of branchless banking and remote banking activities. Through these innovations, customers no longer have to go to the bank directly. Furthermore, mobile device technology appears to make financial transactions easier. These innovations made direct financing and intermediation popular, which is predicted to replace inefficient and expensive indirect financing and financial intermediation [1]. Mobile payment technology is increasingly well-known for the popularity of mobile devices [2]. Digital payment methods have become a worldwide payment phenomenon. In the Jordan Mobile Payment (JoMoPay) system, it can save cost, time, and effort [3]. One example of a startup in the United States engaged in digital payment systems is PayPal; PayPal uses the phone in the operating system to offer its payment services [4]. 


\title{
International Journal of Research and Applied Technology
}

\author{
1(1)(2021) 9-16
}

Journal homepage: https://ojs.unikom.ac.id/index.php/injuratech

Mobile payments are receiving great attention globally, from consumers to merchants, as an alternative to use credit cards, cash, or check. The potential of this technology is enormous. The comparison with our research is that our research discusses one of the functions of financial technology in payment facility methods. Meanwhile, the previous research discusses financial technology as the main determinant of mobile payment adoption [2]. According to Laudon and Traver. E-commerce is a business transaction conducted using the internet and web that meets two conditions, namely all transactions carried out with digital media technology (especially transactions that occur through the internet and web) and currency movements in those transactions. The statement was in keeping with what Laudon and Traver said, as technology-evolved transactions were much easier to do over the internet and the web. The difference with our research is that our research discusses one of the functions of financial technology in payment facility methods, while the previous research discusses the ease of using financial technology in business transactions [5]. In cashless payment, payment transactions can be made without making physical contact between the seller and the buyer. Online trading trends through several marketplaces can be done with several non-cash payment methods. In Indonesia, there are several top enterprise startups such as Gojek, Traveloka, TokoPedia, BukaLapak, and OVO. Our research discussed one of the functions of financial technology in payment facility methods, while the previous research discusses digital payment in the form of cashless payment in Indonesia [6]. According to Bastian, the transaction is a meeting between two parties (seller and buyer) that is mutually beneficial with the data, evidence, supporting documents entered into the journal after going through the recording. In practice, e-commerce is grouped into two segments: Business to Consumer (B2C) and Business-to-Business (B2B). Our research discussed one of the functions of financial technology in payment facility methods, while the previous research discusses the use of FinTech in the business world [7]. India has to use the digital payment system because there is often a long queue in front of the bank, and the self-service cash platform (ATM) is closed due to limited cash supply. One important solution is the alternative mode of digital payment systems. The Indian government notified citizens of the implementation of the cash withdrawal limit. The scarcity of cash is driving the adoption of alternative methods of faster digital payment systems. Our research discussed one of the functions of financial technology in payment facility methods, while the previous research discussed digital payments first used in India [8]. Ecommerce Security is part of the Information Security Framework, which is specifically applied to components that affect e-commerce, including data security, computer security, and other broader areas of the information security framework. The difference with our research is that we discussed one of the functions of financial technology in payment facility methods, while the previous research discusses data security in digital payment systems [9]. According to Piyus Kumar in his research, in India, Digital payments change people's buying behavior, preventing the black money market. Besides, digital payments help the government keep records of all transactions. Digital Payment habits have changed following demonetization. People had no other choice but to transact. Therefore, Indian society moved slowly from cash to digital transaction systems [10].

This study analyzes the impact of digital payment system development on cash in the digital age. Besides, it is also to minimize the risks posed by digital payment systems and prevent inflation due to a large amount of cash in circulation. In this study, we used the descriptive qualitative method. 


\section{International Journal of Research and Applied Technology}

$$
\text { 1(1)(2021) 9-16 }
$$

Journal homepage: https://ojs.unikom.ac.id/index.php/injuratech

\section{Method}

This research approach was descriptive qualitative. The basis of the theory acts as a guide to focus research under the facts in the field. This research was using a qualitative method that aims to understand the studied object. The purpose is to develop the concept of sensitivity to the problem at hand, explain the reality related to grounded theory, and develop an understanding of one or more of the phenomena that are faced. The data collected is generally qualitative. Respondents in the qualitative method are still growing (snowball) purposively until the data collected is considered satisfactory or saturated (redundancy).

\section{Results and Discussion}

In the advancement of technology in today's era, many changes are felt by the public all in the easy-to-access payments in every transaction. It is proven that electronic payments are increasing when they are doing online shopping. This habit shows that people have already taken advantage of digital payment systems in their transactions. It certainly opens up opportunities for technology-based financial services to continue to grow in Indonesia, one of which is the digital payment industry. Many people use the internet as a global communication medium, including payments, capital management, lending, financing, securities trading, and insurance services. For some people, it is practical and does not take much time. From the previous research, the factors that influence a person to transact online, namely easy, no need to leave the house, fast, and safe so that everyone can minimize going out of the house during the Covid-19 pandemic. In this rapid technological development, online transaction methods must also be more concerned with their security. This research aims to analyze the impact of digital payment system development on cash in the digital age. Besides, to minimize the risks posed by the use of digital payment systems [11,12].

There were only nine companies that carried out FinTech activities. However, the number increased to 25 companies in 2011-2012. Relatively, in that year, the number of FinTech companies grew only about $177.78 \%$, lower than the growth in 2006-2007, which is reached about $300 \%$. The number of FinTech companies increased by 15 to 40 companies or grew by about $60 \%$ in 2013-2014. A great development occurred in 2014-2016, where the number of FinTech companies increased by 125 companies to 165 companies. Therefore, there was an increase in the number of FinTech companies by $312.5 \%$ compared to the previous year. The illustration is shown in Figure 1.

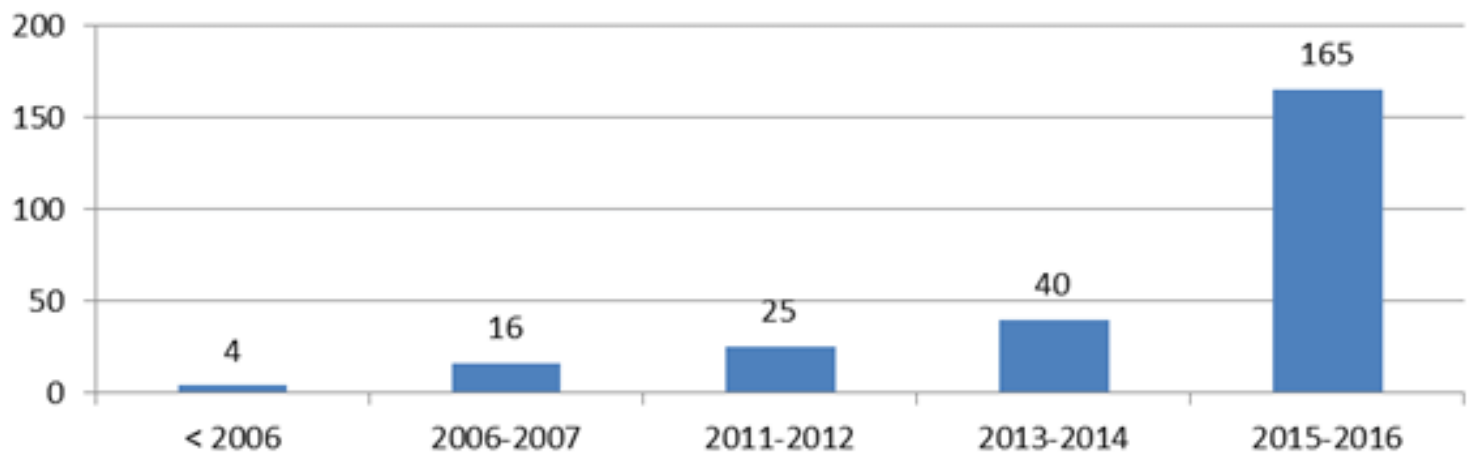

Figure 1. Number of FinTech Companies in Indonesia, 2006 - 2016 Source : Asosiasi FinTech Indonesia dan OJK, (2017). 


\section{International Journal of Research and Applied Technology}

$$
\text { 1(1)(2021) 9-16 }
$$

Journal homepage: https://ojs.unikom.ac.id/index.php/injuratech

From the interviews that we conducted for 15 participants; the results of the interview that were obtained is shown in Table 1.

Table 1. Interview Results

\begin{tabular}{|c|c|c|}
\hline No & Question & Answer \\
\hline 1. & $\begin{array}{l}\text { What do you think about digital } \\
\text { payment systems? }\end{array}$ & $\begin{array}{l}\text { A system that makes it easier for us } \\
\text { to buy things without having to give } \\
\text { us cash }\end{array}$ \\
\hline 2. & $\begin{array}{l}\text { Do you think this digital payment } \\
\text { system is useful in the current } \\
\text { situation? }\end{array}$ & $\begin{array}{l}\text { It is very helpful in payment because } \\
\text { it is effective and efficient. It is also } \\
\text { makes it easier when we want } \\
\text { something but during this } \\
\text { pandemic, we have to stay away } \\
\text { from Covid-19 }\end{array}$ \\
\hline 3. & $\begin{array}{l}\text { Do you think there are difficulties in } \\
\text { applying the digital system payment } \\
\text { (OVO) }\end{array}$ & $\begin{array}{l}\text { Some have difficulties but the } \\
\text { majority do not have problems } \\
\text { because it is not difficult to follow } \\
\text { the instruction. Also, as a young } \\
\text { generation, we must be able to open } \\
\text { with technology because } \\
\text { technological advances make it } \\
\text { easier for us to access quickly } \\
\text { without difficulty. }\end{array}$ \\
\hline 4 & $\begin{array}{l}\text { Are you one of the people who often use } \\
\text { digital payments or not? }\end{array}$ & $\begin{array}{l}\text { Of course, using digital payments } \\
\text { because it is made to be easy to } \\
\text { access such as buying something and } \\
\text { others via online so that you do not } \\
\text { have to shop offline. }\end{array}$ \\
\hline
\end{tabular}

The features in this digital payment system are made in such a way as to make it easier for users to transact, and we can choose a variety of options to use this digital payment platform according to the wants, such as OVO, Gopay, Dana, and T-cash. The illustrations are shown in Figures 2 and 3.

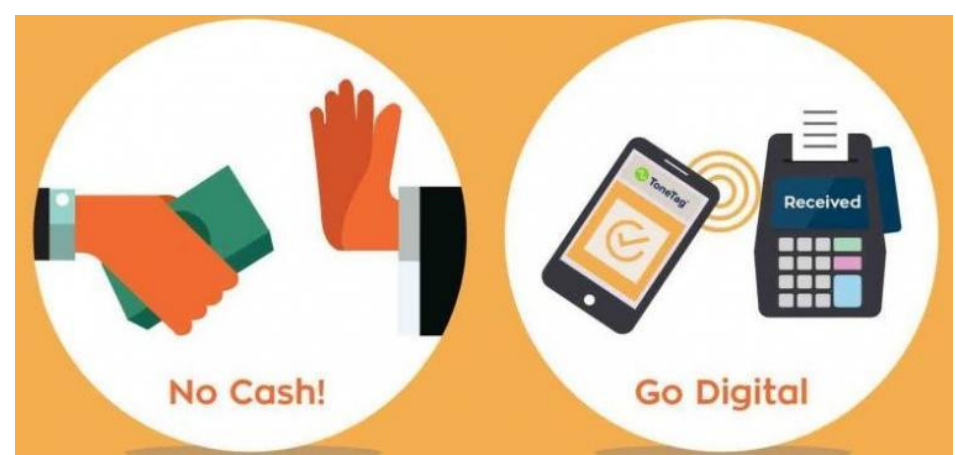

Figure.2 Cashless Payment Illustration

Source: Visionet Internasional, accessed February 2021 


\section{International Journal of Research and Applied Technology}

$$
\text { 1(1)(2021) 9-16 }
$$

Journal homepage: https://ojs.unikom.ac.id/index.php/injuratech
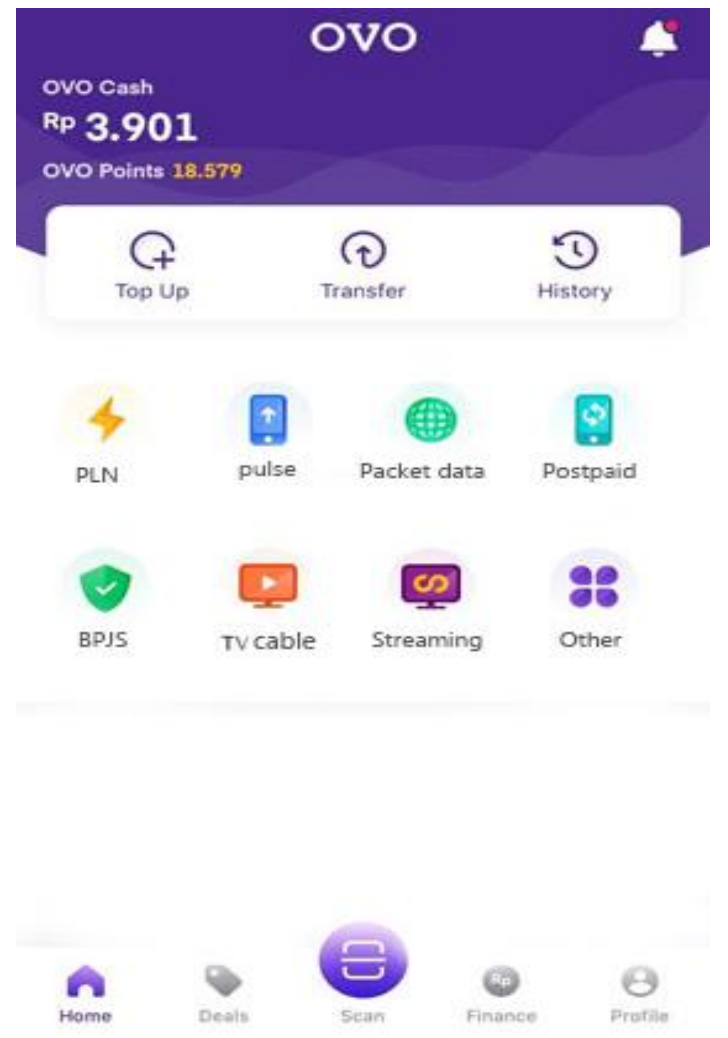

Figure 3. Home Page of OVO Application

Source: Visionet Internasional, accessed February 2021

OVO, an application developed by PT. Visionet Internasional in 2016 is a digital financial service from Indonesia that makes users easier to transact at merchants. OVO is an application that offers financial services, payments, and loyalty points backed by Lippo Group's digital arm. However, they were granted permission to operate as a FinTech company on September 25, 2017. Another example is shown in Figure 4. 


\section{International Journal of Research and Applied Technology}

$$
\text { 1(1)(2021) 9-16 }
$$

Journal homepage: https://ojs.unikom.ac.id/index.php/injuratech

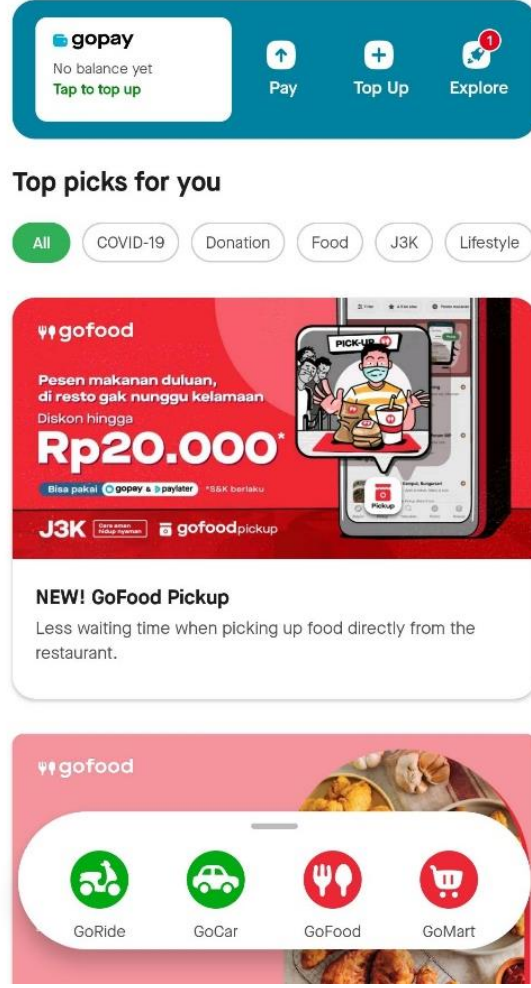

Figure 4. Home Page of GO-JEK Application

GO-JEK is an Indonesian technology company that provides transportation through ojek services. The company was founded in 2010 in Jakarta by Nadiem Makarim. On December 15, 2017, Gojek announced its acquisition of three financial technology companies, namely Midtrans, Mapan, and Kartuku to support GoPay's expansion. Kartuku is a Payment Service Provider (PSP) and Third Party Processor (TPP) company. Kartuku, which has operated more than 150 thousand payment instruments in offline outlets and has cooperated with nine acquirer banks, will be focused on developing the use of GoPay offline. Furthermore, another example is shown in Figure 5. 


\section{International Journal of Research and Applied Technology}

$$
\text { 1(1)(2021) 9-16 }
$$

Journal homepage: https://ojs.unikom.ac.id/index.php/injuratech
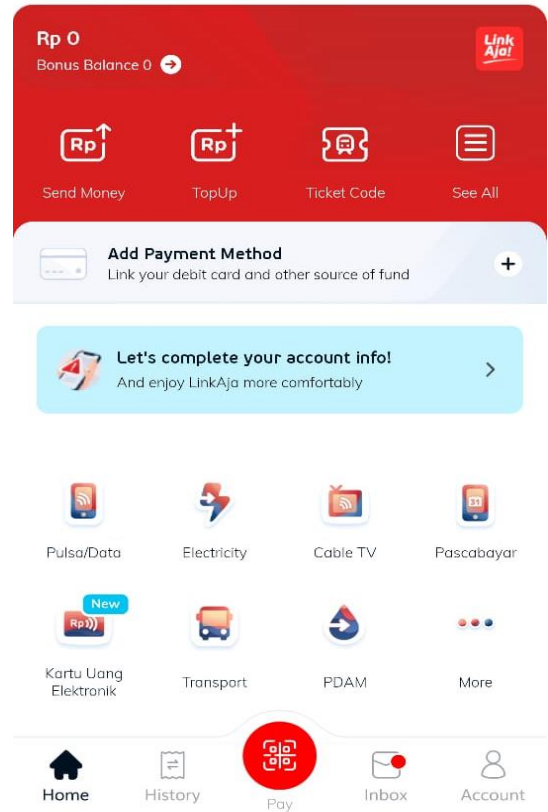

Figure 5. Home Page of LinkAja! Application

LinkAja! is an interbank network in Indonesia. It connects four state-owned banks and Telkomsel. The banks featured are Bank Mandiri, Bank Tabungan Negara, BNI 46, and Bank Rakyat Indonesia. The network is owned by the Association of State-Owned Banks (HIMBARA). These networks provide cash withdrawal and investigation services on their networks. On March 26, 2020, Linkaja collaborated with Telcoin, a low-cost blockchainpowered instant remittance service.

\section{Conclusion}

Financial Technology (FinTech)'s impact on Indonesia's economy is very diverse, where businesses must follow the development of an increasingly modern era. Innovating not only on products but also on its finances that utilize technology. With FinTech, some community activities can be efficient, so that it is easy. However, the advantages come from FinTech itself and some threats that the government needs to be aware of so that regulation can be made immediately. Therefore, there is a clear legal umbrella regarding FinTech. Based on the available data obtained results, countries with higher economic rates tend to have higher transactions.

\section{References}

[1] Financial Stability Board. 2017. FinTech credit: Market structure, business models and financial stability implications. May 2017.

[2] Oliveira, T., Thomas, M., Baptista, G., \& Campos, F. 2016. Mobile payment: Understanding the determinants of customer adoption and intention to recommend the technology. Computers in Human Behavior, 61, pp. 404-414.

[3] Al-Okaily, M., Lutfi, A., Alsaad, A., Taamneh, A., \& Alsyouf, A. 2020. The determinants of digital payment systems' acceptance under cultural orientation differences: The case of uncertainty avoidance. Technology in society, 63, pp. 101367. 


\section{International Journal of Research and Applied Technology}

$$
1(1)(2021) 9-16
$$

Journal homepage: https://ojs.unikom.ac.id/index.php/injuratech

[4] Kazan, E., Tan, C. W., \& Lim, E. T. 2014. Towards a framework of digital platform disruption: A comparative study of centralized \& decentralized digital payment providers. ACIS.

[5] Laudon, K. C., \& Traver, C. G. 2016. E-commerce: business, technology, society.

[6] Abdillah, L. 2020. Model Transaksi Keuangan Perdagangan Elektronik (E-Commerce Financial Transaction Model). Perdagangan Elektronik: Berjualan di Internet (Electronic Commerce: Selling on the Internet). Medan: Yayasan Kita Menulis., Forthcoming.

[7] Ginantra, N. L. W. S. R., Simarmata, J., Purba, R. A., Tojiri, M. Y., Duwila, A. A., Siregar, M. N. H., ... \& Siswanti, I. 2020. Teknologi Finansial: Sistem Finansial Berbasis Teknologi di Era Digital. Yayasan Kita Menulis.

[8] Sivathanu, B. 2019. Adoption of digital payment systems in the era of demonetization in India: An empirical study. Journal of Science and Technology Policy Management.

[9] Niranjanamurthy, M., Kavyashree, N., Jagannath, S., \& Chahar, D. 2013. Analysis of ecommerce and m-commerce: advantages, limitations and security issues. International Journal of Advanced Research in Computer and Communication Engineering, 2(6), pp. 23602370.

[10] Kumar, P., \& Chaubey, D. S. 2017. Demonetization and its impact on adoption of digital payment: Opportunities, issues and challenges. Abhinav National Monthly Refereed Journal of Research in Commerce E Management, 6(6), pp. 15.

[11] Soegoto, E. S., \& Sumantri, M. B. R. 2020. The Influence of Digital Wallet. In IOP Conference Series: Materials Science and Engineering, 879(1), p. 012122.

[12] Suroto, S., \& Nurdin, N. 2021. Economic Analysis: Solar Panels Application of NFT (Nutrient Film Technique) Hydroponic System in Bandung. ASEAN Journal of Science and Engineering Education, 1(1), pp. 21-30. 